ISSN 2077-1827. Гуманізація навчально-виховного процесу. 2019, №. 6 (98)

РОЗДІЛ. ВИЩА ШКОЛА

УДК 37.013.74

\title{
ДЬОМІНА Вікторія
}

доктор педагогічних наук, доцент кафедри романо-германських мов i перекладу Національного університету біоресурсів та природокористування України

вул. Генерала Родімцева 1, м. Київ, 03041

E-mail: diomina@,nubip.edu.ua

\section{СНІЦАР Валентина}

кандидат філологічних наук, доцент кафедри романо-германських мов $\mathrm{i}$ перекладу Національного університету біоресурсів та природокористування України

вул. Генерала Родімцева 1, м. Київ, 03041

E-mail: vl.snitsar@gmail.com

\section{НІКОЛЬСЬКА Ніна}

кандидат філологічних наук, доцент кафедри романо-германських мов $\mathrm{i}$ перекладу Національного університету біоресурсів та природокористування України

вул. Генерала Родімцева 1, м. Київ, 03041

E-mail: nina777-07@,hotmail.com

\section{ПЕДАГОГІЧНІ УМОВИ ФОРМУВАННЯ ПРОФЕСІЙНОЇ КУЛЬТУРИ СПІЛКУВАННЯ У МАЙБУТНІХ ПЕРЕКЛАДАЧІВ}

Анотація. У запропонованій статті авторами представлено теоретичні основи підготовки майбутніх перекладачів, у яких сформована загальна та професійна культура спілкування, адаптуються до життєвих умов, вміють вдало використовувати свої знання, вміння, навички у нових професійних ситуаціях 3 метою ефективного вирішення професійних проблеми; здатність до адекватної комунікативної взаємодії в різними соціальними групами та етносами; прагнення до самостійного рефлексивного мислення, самоосвіти, постійного вдосконалення моральності, інтелекту і культурного рівня.

Обгрунтовано концептуальні засади розробки педагогічних умов професійної культури спілкування у майбутніх перекладачів: визначено методологічні підходи; розкрито особливості та специфіку процесу професійної підготовки перекладачів та формування їх особистості у сучасних геополітичних умовах; визначені перспективи розвитку системи виховання майбутніх перекладачів в контексті діалогу культур в цілісному освітньому процесі вищої школи.

Визначено комплекс педагогічних умов, що діють у цілеспрямовано створеному білінгвальному середовищі закладу вищої освіти, в якому у взаємодії представлені сукупність психологічних і педагогічних чинників, що дозволяють ефективно здійснювати виховну та навчальну діяльність та формувати культуру срілкування, що сприяє підвищенню ефективності (C) Дьоміна В., Сніцар В., Нікольська Н., 2019 
навчально-виховного процесу; модульне конструювання змісту іншомовної освіти в процесі професійної підготовки перекладачів та його соціокультурне наповнення; створення культурно-виховного білінгвального середовища; залучення студентів до активної взаємодії в інтегрованому полікультурному просторі вузу; діалогічна взаємодія між суб'єктами освітнього процесу.

Ключові слова: білінгвальне середовище, діалог культур, культура спілкування, модульне конструюванняю, педагогічні умови, перекладач.

Постановка проблеми у загальному вигляді та іiї зв'язок 3 важливими науковими та практичними завданнями. Відповідно до змін у світі сьогодні зростають вимоги до фахівця, який повинен бути конкурентоспроможним на ринку праці, успішним у професійній самореалізації і кар'єрі. У таких умовах якісна професійна освіта має забезпечувати формування фахівця 3 достатнім рівнем професійних знань, умінь і навичок, сукупністю особистісних можливостей і досвіду. Саме тому провідною тенденцією сучасних закладів вищої освіти є підготовка фахівців високої загальної та професійної культури, які вміють адаптуватися до життєвих умов, що постйно змінюються, застосовувати свої знання, уміння, навички в новій професійній ситуації 3 метою ефективного рішення проблеми; мають соціально-відповідальну поведінку та займають активну громадянську позицію; здатні до адекватної комунікативної взаємодії у різних соціальних групах, самостійного рефлексивного мислення, самоосвіти; постійного вдосконалення власної моральності, інтелекту, підвищення культурного рівня.

Аналіз останніх досліджень і публікацій. Багато науковців і педагогів досліджують поняття «культура спілкування», інтерес до якого виник ще у період глобального соціального оновлення, прагнення до відкритого суспільства та інтеграції до світового культурно $\square$ освітній простір. Аналізу виховних можливостей білінгвальної культури спілкування, методів і засобів формування окремих компонентів культури спілкування присвячені праці В.Авроріна, У. Вайнраха, Є. Вєнєвцевої, М. Михайлова, Н. Протченка, С. Трєскова, Л. Щерби та інших. Формування культури спілкування у майбутніх перекладачів відбувається у цілісному освітньо-виховному процесі закладу вищої освіти. Тому новий підхід у галузі професійного виховання полягає в організації процесу формування особистості спеціаліста на основі взаємозв'язку, взаємного проникнення всіх видів виховання, покликаних формувати загальну культуру особистості у ії культурологічному аспекті.

Велике значення також мають i наукові розробки 3 удосконалення технологій навчально-виховного процесу у вищих закладах освіти представлені в роботах І. Беха, М. Свтуха, Л. Кондрашової, Н. Кузьміної, В.Лозової, Н. Тализіної, О. Семашка, О. Соколова, Г. Шевченко.

Метою статті є обгрунтування педагогічних умов культури спілкування у майбутніх перекладачів у цілісному освітньо-виховного процесі закладу вищої освіти.

Виклад основного матеріалу 3 повним обгрунтуванням отриманих наукових результатів. Ефективність процесу формування культури 
ISSN 2077-1827. Гуманізація навчально-виховного процесу. 2019, №. 6 (98)

РОЗДІЛ. ВИЩА ШКОЛА

спілкування у майбутніх перекладачів багато у чому залежить від сукупності закономірностей, принципів, функцій навчання, виховання та самовдосконалення студентів - майбутніх перекладачів, методики, форм, засобів та педагогічних умов, за яких буде організовано цілісний освітньовиховний процес. Адже умова - складова будь-якого процесу, зокрема i процесу формування культури спілкування у майбутніх перекладачів.

Поняття «умова» у філософському плані розглядається як категорія, яка відображає ставлення предмету до оточуючих його явищ, без яких цей предмет не може існувати й розвиватися (Шинкарук, с. 531).

Для обгрунтування педагогічних умов, котрі будуть сприяти формуванню культури спілкування у майбутніх перекладачів слід уточнити їх тлумачення відповідно до предмету дослідження. Аналіз наукової літератури дозволяє стверджувати, що термін «педагогічна умова» визначається як деяка обставина, що сприяє формуванню та розвитку педагогічних систем, явищ, процесів, якостей особистості Н. Іполітова (Іполітова, 2006).

Педагогічні умови - це цілеспрямовано створене середовище, в якому в тісній взаємодії представлено сукупність психологічних і педагогічних чинників (відносин, засобів тощо), що дозволяють педагогові ефективно здійснювати виховну або навчальну роботу (Бражнич, 2001).

Під педагогічними умовами формування культури спілкування у нашому дослідженні виховання ми розуміємо таку сукупність факторів, які ефективно впливатимуть на формування та розвиток усіх компонентів білінгвальної культури та культури спілкування у майбутніх перекладачів як складової їх професійної підготовки, вихованості та загального культурного розвитку з позиції діалогу культур.

В контексті нашого дослідження педагогічні умови формування культури спілкування у майбутніх перекладачів повинні бути визначеними, виходячи iз сутності i структури цього феномена, i забезпечувати максимальний $\mathrm{i}$ детермінований вплив на функціонування усіх його компонентів (когнітивного, емотивного, комунікативного, мотиваційного, саморегуляційного, процесуального та естетичного). При цьому зміст сформульованих педагогічних умов повинен укладатися в спроектовану організаційно-методичну систему професійної підготовки та виховання майбутніх перекладачів у закладі вищої освіти.

Визначаючи комплекс педагогічних умов формування культури спілкування у майбутніх перекладачів, ми враховували: соціальне замовлення держави і суспільства, відбите в нормативно-правових документах; визначені методологічні підходи (системно-синергетичний, крос-культурний, особистісно-орієнтований, діяльнісно-рефлексивний, середовищний), що складали базу нашого дослідження; особливості і специфіку процесу професійної підготовки філологів та їх виховання в контексті міжетнічного спілкування; внутрішні особливості розробленої організаційно-методичної системи формування культури спілкування студентів (білінгвальне культурно-виховне середовище); перспективи розвитку системи виховання 
майбутніх перекладачів в контексті діалогу культур у цілісному освітньому процесі вищої педагогічної школи (Дьоміна, 2017, с. 119-128).

Теоретичний аналіз досліджуваної проблеми, закономірності, принципи, компоненти та підходи науковців до визначення педагогічних умов дозволили виокремити педагогічні умови, що дозволять ефективно здійснити процес формування культури спілкування у майбутніх перекладачів у цілісному освітньо-виховному середовищі університету: дидактичні, виховні, акмеологічні.

Дидактичні умови забезпечують системно-технологічну організацію освоєння студентами змісту психолого-педагогічних, лінгвістичних, культурологічних дисциплін, спрямованих на білінгвальний розвиток особистості майбутнього перекладача у наступних напрямках: в інтелектуальному, що формують професійні мовні, соціокультурні та лінгвокультурологічні знання; в морально-етичному, що формують моральноетичні якості білінгвальної особистості, такі як емпатія, толерантне ставлення до носіїв іншої культури; ціннісно-естетичному, що формують цінності краси, гармонії, художньої форми мистецького твору. До дидактичних умов відносимо: побудова змісту i структури навчально-виховного процесу педагогічного навчального закладу через інтеграцію навчальних дисциплін у відповідності із завданнями і основними компонентами білінгвальної культури; модульна побудова змісту іншомовної освіти у процесі професійної підготовки перекладачів та його соціокультурне наповнення; відбір евристичних та проектних завдань для освоєння психолого-педагогічних, лінгвістичних та культурологічних дисциплін; застосування інтерактивних технологій у навчальному процесі; формування позитивної мотивації студентів до вивчення і освоєння професійно орієнтованих та лінгвокультурологічних дисциплін на основі їх інтеграції та максимальної інтенсифікації освоєння.

Виховні умови зумовлюються спеціальною, цільовою організацією педагогом виховної діяльності, міжособистісної взаємодії та взаєморозуміння, діалогічним спілкуванням між усіма суб'єктами освітньо-виховного процесу. До виховних умов відносимо наступні: реалізація ціннісно орієнтуючого діалогу творчих взаємодій викладачів і студентів у навчальній та позааудиторній роботі через включення у практичну міжкультурну комунікативну діяльність, під час якої актуалізується та формується професійно-творчий потенціал майбутнього перекладача; створення доброзичливого моральнопсихологічного клімату в колективі, а також урахування емоційного самопочуття кожного студента; педагогічна підтримка викладачами єдиного мовного режиму i корекція розвитку культури спілкування майбутніх перекладача відповідно до іiі компонентів; створення полікультурного простору та білінгвального культурновиховного та соціально-інтегруючого середовища вищого педагогічного навчального закладу.

Акмеологічні умови спрямовані на стимулювання і підтримку високого рівня особистісної активності студентів в процесі освоєння іншої культури і мови, професійного зростання мовленнєвої особистості і становлення іiі культури. Акмеологічними умовами формування культури спілкування у 
майбутніх перекладачів визначаємо: установка на білінгвальний саморозвиток, готовність до самопізнання іншої мови, культури, усвідомлення необхідності іiі постійного пізнання 3 метою власного культурного вдосконалення; самоактуалізація здібностей професійної та власної рефлексії, саморегуляція вчинків 3 позицій норм i правил міжкультурної взаємодії; орієнтація педагогічного процесу на суб'єктивну позицію студента як носія загальнолюдських цінностей з позиції діалогу культур.

Іншомовна освіта, яка лежить в основі формування культури спілкування майбутніх філологів, повинна бути спрямована на те, щоб забезпечити входження молодого спеціаліста в іншу культуру, що здійснюється на основі освоєння лінгвокультурологіних знань. Для цього необхідно забезпечити інтеграцію у викладанні дисциплін загально професійного, гуманітарного та художньо-естетичного блоків, що розглядається нами як результат взаємодії певних елементів, які вступають у взаємозв'язок, утворюючи нову цілісність, якій притаманні ознаки системності.

Міжпредметна інтеграція відбувається при виділенні в різних дисциплінах спільного наскрізного змісту, на основі якого здійснюється міжпредметні узгодження відповідності навчальних програм, що дозволяє синхронно вивчати теми. Взаємодія i інтеграція сприяють цілісному сприйняттю студентами культури певного історичного періоду, що досліджується, шляхом встановлення міжпредметних зв'язків; розкривають гносеологічні проблеми, без яких неможливо системне засвоєння основ будьяких наук, залучаючи студентів до оперування пізнавальними методами: абстрагування, моделювання, аналогія, узагальнення тощо. Ця системна діяльність спрямована на послідовний когнітивний, емотивний, комунікативний, художній, рефлексивний розвиток студентів, що забезпечує розвиток кругозору, вдосконалює професійні якостей вчителяфілолога, його властивостей характеру, розумових процесів, комунікативної активності.

Професійний розвиток особистості майбутнього перекладача пов'язаний з придбанням ним власного соціального та педагогічного досвіду, 3 розвитком умінь саморефлексії, які дозволяють адекватно взаємодіяти в соціально-детермінованих ситуаціях у сучасному освітньому, професійному та полікультурному просторі. Це відбувається, якщо навчально-виховний процес у закладі вищої освіти забезпечує занурення студентів - майбутніх перекладачів - у культурно-виховне білінгвальне середовище, дозволяючи вихід за межі навчального спілкування, i спрямовує на практичне застосування отриманих знань, навичок i умінь в соціально-значущих ситуаціях в соціально-значущій діяльності. При цьому включення студентів у культурно-виховне білінгвальне середовище ЗВО має стимулювати осмислення сформованих раніше загальнолюдських цінностей, соціальних уявлень і порівняння їх з уявленнями інших людей, забезпечувати досвід спілкування, досвід діяльності на основі засвоєних цінностей іншої культури, досвід взаємодії і широкого пошуку інформації.

Зміст виховної роботи з формування культури спілкування у майбутніх перекладачів грунтується на інтеграції наступних важливих складових: а) мови, 
що відображає культуру народу; б) культури, що передає національні особливості суспільно-історичних умов розвитку певної нації; в) людини, яка проходить формування в освітній та комунікативній діяльності у полікультурному просторі (Приходченко, 2007).

В межах нашого дослідження залучення студентів в культурновиховне білінгвальне середовище здійснюється в наступних напрямках: участь студентів у позааудиторній соціокультурній роботі; участь студентів в міжнародному освітньому співробітництві; участь студентів в громадському студентському самоврядуванні. Важливою для реалізації виховних умов, що сприяють формуванню культури спілкування у майбутніх перекладачів - $є$ позаудиторна робота як основа виховання особистості студента, певна «форма розширення освітнього простору, своєрідний тренінг 3 використання широкої гами студентських знань не тільки в конкретній галузі, але i на стику наук, розширення сфери спілкування «студент-викладач», «студент-студент» (Вєнєвцева, 2013).

Одним 3 важливих засобів формування культури спілкування у майбутніх перекладачів - $\epsilon$ мистецтво, що здатне максимально впливати на їх культурно-духовний, професійний та соціальний розвиток. Саме тому членами кафедри романо-германських мов i перекладау НУБіП України створено науковий гурток «Культура білінгвального спілкування майбутнього перекладача», що діє на гуманітарно-педагогічному факультеті, знайомить студентів 3 художньою спадщиною англійської культури, допомогає оволодіти знаннями щодо культури професійного та білінгвального спілкування, формує вміння та навички культури білінгвального спілкування у майбутніх перекладачів. Завдяки цій роботі студенти вивчають кращі зразки англійської художньої літератури, беруть участь у дослідницьких проектах, що реалізуються суб'єктами міжнародної діяльності НУБіП України спільно із колегами університету, таких як: створення міжнародних збірників - коментарів до художніх творів, наукові публікації у міжнародних журналах. Студенти знайомляться 3 формами культурного життя і системою соціальних цінностей іншої культури через призму власної та через активний діалог 3 нею. При цьому вони мають можливість донести до своїх співрозмовників свої власні духовні цінності, розвиваючи позитивну моральну оцінку своєї культури, свого соціуму.

Впроваджуючи педагогічні умови, ми намагалися забезпечити організаційно-методичний i психолого-педагогічний супровід професійної підготовки та виховання майбутніх перекладачів в контексті діалогу культур; вдосконалити систему методичної підготовки педагогічних працівників для роботи зі студентами у полікультурному просторі закладу вищої освіти; визначаючи зміст, форми i методику процесу формування кожного 3 компонентів білінгвальної культури у майбутніх перекладачів у реальних умовах освітньо-виховного середовища сучасного університету.

Реалізація комплексу педагогічних умов як запорука підвищення якості професійної підготовки перекладача та їх виховання в контексті діалогу культур забезпечує: формування у студентів цілісної системи 
ISSN 2077-1827. Гуманізація навчально-виховного процесу. 2019, №. 6 (98)

РОЗДІЛ. ВИЩА ШКОЛА

соціокультурних знань (психолого-педагогічних, культурологічних, соціологічних, лінгвістичних, історичних тощо); розвиток соціокультурних умінь (виявляти загальне і культурно-специфічне, міжкультурної взаємодії; уміння обробляти й узагальнювати інформацію, класифікувати їі за певними ознаками, приймати i розділяти цінності) розвиток соціальнозначущих якостей і здібностей (саморегуляція, емпатія, толерантність, здатність до сприйняття гармонії i краси, здатність до естетичного сприйняття та художньо-естетичної оцінки літературних та художніх мистецьких творів).

Висновки з дослідження і перспективи подальших розвідок у цьому напрямі. Отже, використання комплексу педагогічних умов забезпечує якість освітньо-виховного процесу сучасного закладу вищої освіти. Також допомогає зверненню всіх компонентів освіти до людини, як суб'єкта культури, що здатна постійно саморозвивати професійну культуру спілкування як складного комплексу соціокультурних, лінгвістичних, культурологічних знань, умінь, якостей, що забезпечують соціалізацію й культурну інтеграцію особистості у сучасному полікультурному просторі.

Комплекс педагогічних умов сприяє формуванню професійної культури спілкування майбутніх перекладачів і забезпечує соціальну адаптацію та самоствердження особистості в мультикультурному середовищі сучасного освітнього простору; готує студентів до уміння вести діалог культур 3 представниками інших етносів, розуміючи їх культурно-мовленнєву специфіку.

Проте сучасній науці бракує теоретичного обгрунтування змісту та структури, методів, засобів і форм формування білінгвальної культури спілкування, критеріїв, показників та рівнів піi вихованості, що дозволяє констатувати недостатню розробленість даної проблеми. $€$ потреба у комплексному підході до пошуку ресурсів та механізмів формування білінгвальної культури спілкування майбутніх перекладачів.

\section{СПИСОК ВИКОРИСТАНОЇ ЛІТЕРАТУРИ}

1. Вєнєвцева Є. В. (2013) Актуальність дослідження проблеми виховання білінгвальної культури спілкування студентів вищих педагогічних закладів. Підготовка майбутніх керівників навчальних закладів до інноваційного управління. Наукова мобільність у програмі «Горизонт 2020» (дї̈ Марії Склодовської-Кюрі): матеріали Всеукраїнського семінару 3 міжнародного участю (Полтава, 8 жовтня 2013 р.) Київ, 11-12.

2. Дьоміна В. В. (2017) Виховання білінгвальної культури у майбутніх учителів іноземної мови: теоретико-методологічний аспект. Духовність особистості : методологія, теорія $i$ практика : збірник наукових праць. Сєвєродонецьк: вид-во СНУ ім. В. Даля 2 (77), 119-128.

3. Ипполитова Н. В., Колесников М. А. Соколова Е. А.(2006) Система профессиональной подготовки студентов педагогического вуза: личностный аспект: монография. Шадринск: Исеть, 236 с.

4. Приходченко К.I. (2007) Творче освітньо-виховне середовище навчального закладу: навч. посібник. Х. : Основа, 160. 
ISSN 2077-1827. Гуманізація навчально-виховного процесу. 2019, №. 6 (98)

РОЗДІЛ. ВИЩА ШКОЛА

5. Шинкарук В.І., Озадовська Л.В., Поліщук Н.П. (2002) Філософський енциклопедичний словник. Київ: Абрис, 742 с.

Стаття надійшла до редакції 19.11.2019.

\section{ДЁМИНА Виктория}

доктор педагогических наук, доцент кафедры романо-германских языков и перевода Национального университета биоресурсов и природопользования Украины

ул. Генерала Родимцева 1, г. Киев, 03041

E-mail: diomina@nubip.edu.ua

\section{СНИЦАР Валентина}

кандидат филологических наук, доцент кафедры романо-германских языков и перевода Национального университета биоресурсов и природопользования Украины

ул. Генерала Родимцева 1, г. Киев, 03041

E-mail: vl.snitsar@gmail.com

\section{НИКОЛЬСКАЯ Нина}

кандидат филологических наук, доцент кафедры романо-германских языков и перевода Национального университета биоресурсов и природопользования Украины

ул. Генерала Родимцева 1, г. Киев, 03041

E-mail: nina777-07@,hotmail.com

\section{ПЕДАГОГИЧЕСКИЕ УСЛОВИЯ ФОРМИРОВАНИЯ} ПРОФЕССИОНАЛЬНОЙ КУЛЬТУРЫ ОБЩЕНИЯ У БУДУЩИХ ПЕРЕВОДЧИКОВ

Резюме. В предлагаемой статье авторами представлены теоретические основы подготовки будущих переводчиков, в которых сформирована общая и профессиональная культура общения, адаптируются к жизненным условиям, умеют удачно использовать свои знания, умения, навыки в новых профессиональных ситуациях с целью эффективного решения профессиональных проблем; способность к адекватной коммуникативного взаимодействия в различными социальными группами и этносами; стремление к самостоятельному рефлексивного мышления, самообразования, постоянного совершенствования нравственности, интеллекта и культурного уровня.

Обоснованы концептуальные основы разработки педагогических условий профессиональной культуры общения у будущих переводчиков: определены методологические подходы; раскрыты особенности и специфику процесса профессиональной подготовки переводчиков и формирования их личности в современных геополитических условиях; определены перспективы развития системы воспитания будущих переводчиков в контексте диалога культур в целостном образовательном процессе высшей школы.

Определен комплекс педагогических условий, действующих в целенаправленно созданном билингвальному среде учреждения высшего образования, в котором во взаимодействии представлены совокупность психологических и педагогических факторов, позволяющих эффективно 
ISSN 2077-1827. Гуманізація навчально-виховного процесу. 2019, №. 6 (98)

РОЗДІЛ. ВИЩА ШКОЛА

осуществлять воспитательную и учебную деятельность и формировать культуру срилкування, что способствует повышению эффективности учебновоспитательного процесса; модульное конструирование содержания иноязычного образования в процессе профессиональной подготовки переводчиков и его социокультурное наполнение; создание культурновоспитательного билингвального среды; привлечение студентов к активному взаимодействию в интегрированном поликультурном пространстве вуза; диалогическое взаимодействие между субъектами образовательного процесса.

Ключевые слова: билингвальное среду, диалог культур, культура общения, модульное конструюванняю, педагогические условия, переводчик.

\section{DOMINA Viktoriia}

Doctor of Pedagogical Sciences, Associate Professor of the Department of Romance and Germanic Languages and Translation National University of Life and Environmental Sciences of Ukraine

Henerala Rodimtseva Str.19 building 1, of.22, Kyiv, 03041

E-mail: domina@,nubip.edu.ua

\section{SNITSAR Valentina}

Candidate of Philological Sciences, Associate Professor of the Department of Romance and Germanic Languages and Translation National University of Life and Environmental Sciences of Ukraine

Henerala Rodimtseva Str.19 building 1, of.22, Kyiv, 03041

E-mail: vl.snitsar@gmail.com

\section{NICKOLSKA Nina}

Candidate of Philological Sciences, Associate Professor of the Department of Romance and Germanic Languages and Translation National University of Life and Environmental Sciences of Ukraine

Henerala Rodimtseva Str.19 building 1, of.22, Kyiv, 03041

E-mail: nina777-07@,hotmail.com

THE PEDAGOGICAL CONDITIONS OF FORMING A PROFESSIONAL CULTURE OF COMMUNICATION IN FUTURE TRANSLATORS

Summary. The proposed article presents the theoretical foundations for the training of future translators, in which the general and professional culture of communication is formed, adapt to living conditions, are able to successfully use their knowledge, skills, skills in new professional situations in order to effectively solve professional problems.

The conceptual bases of development of pedagogical conditions of professional culture of communication at future translators are grounded: methodological approaches are defined; the peculiarities and specifics of the process of vocational training of translators and formation of their personality in modern geopolitical conditions are revealed; the perspectives of development of the 
system of education of future translators in the context of the dialogue of cultures in the holistic educational process of higher education are defined.

Keywords: bilingual environment, dialogue of cultures, culture of communication, modular construction, pedagogical conditions, translator.

Abstract. Introduction. Responding to this, the world today has the necessary work results that must be competitive in the labor market, having achieved success in professional self-fulfillment and carb. In those with a vocational education, it achieves its existence with sufficient equal professional knowledge, skills and navigation, a set of personal opportunities and necessary.

Analysis of publicftions. Many scholars and educators are exploring the concept of «culture of communication», an interest that arose in the period of global social renewal, the desire for an open society and integration into the world cultural and educational space. The work of V. Aurorin, U. Weinrach, E.Venevtseva, M. Mikhailov, N. Protchenko, S. Treskov, L. Shcherby and others is devoted to the analysis of educational possibilities of bilingual communication culture, methods and means of forming individual components of communication culture.

Results. The effectiveness of the process of forming a culture of communication among future translators depends largely on the totality of laws, principles, functions of teaching, education and self-improvement of students future translators, methods, forms, tools and pedagogical conditions under which a holistic educational process will be organized. After all, the condition is a component of any process, including the process of forming a culture of communication with future translators.

The realization of a set of pedagogical conditions as a guarantee for improving the quality of translator's professional training and their upbringing in the context of the dialogue of cultures provides: the formation of students a holistic system of socio-cultural knowledge (psychological-pedagogical, cultural, sociological, linguistic, historical, etc.); development of socio-cultural skills (to show general and cultural-specific, intercultural interaction; ability to process and summarize information, classify it according to certain characteristics, accept and share values) development of socially significant qualities and abilities (selfregulation, empathy, tolerance, tolerance, tolerance ability for aesthetic perception and artistic and aesthetic evaluation of literary and artistic works of art).

Conclusion. Therefore, the use of a set of pedagogical conditions ensures the quality of the educational process of a modern higher education institution. It also helps to address all components of education to a person as a subject of culture, able to constantly develop a professional culture of communication as a complex complex of socio-cultural, linguistic, cultural knowledge, skills, qualities that ensure socialization and cultural integration of personality in modern culture. The complex of pedagogical conditions contributes to the formation of professional culture of communication of future translators and provides social adaptation and self-affirmation of the individual in the multicultural environment of the modern educational space; prepares students for the ability to dialogue cultures with representatives of other ethnic groups, understanding their cultural and speech specificity. 
ISSN 2077-1827. Гуманізація навчально-виховного процесу. 2019, №. 6 (98)

РОЗДІЛ. ВИЩА ШКОЛА

\section{REFERENCES}

1. Venevtseva E.V. (2013) The relevance of research into the problem of upbringing of the bilingual culture of communication between students of higher educational institutions. Preparation of future heads of educational institutions for innovative management. Scientific Mobility in the Horizon 2020 Program (Maria Sklodowska-Curie Actions): Proceedings of the AllUkrainian Seminar on International Participation (Poltava, October 8, 2013) Kyiv, 11-12. [in Ukraine].

2. Domina V.V. (2017) Education of bilingual culture in future foreign language teachers: theoretical and methodological aspect. Personality spirituality: methodology, theory and practice: a collection of scientific works. Severodonetsk: Publishing House of SNU them. V. Dahl 2 (77), 119128. [in Ukraine].

3. Ippolitova N.V., Kolesnikov M.A., Sokolova E.A. (2006) The system of professional training of students of the pedagogical college: personal aspect: monograph. Shadrinsk: Iset, 236. [ in Russia].

4. Prikhodchenko K.I. (2007) Creative educational environment of educational institution: textbook. manual. H.: Basis, 160. [in Ukraine]

5. Shinkaruk VI, Ozadovskaya LV, Polishchuk NP (2002) Philosophical Encyclopedic Dictionary. Kiev: Abris, 742. [in Ukraine].

(переклад зроблено Дьоміною В.В. - д.пед.н., доцентом кафедри романо-германських мов і перекладу Національного університету біоресурсів та природокористування України)

\section{УДК 378.147.88}

\section{КАЙДАН Наталія}

кандидат фізико-математичних наук, доцент, доцент кафедри МНМ та МНІ, ДВНЗ «ДДПУ»

вул. Г. Батюка, 19, м. Слов'янськ, Донецька обл., Україна, 84100

E-mail: kaydannv@gmail.com

\section{ПАЩЕНКО ЗОя}

кандидат фізико-математичних наук, доцент, доцент кафедри МНМ та МНІ, ДВНЗ «ДДПУ»

вул. Г. Батюка, 19, м. Слов’янськ, Донецька обл., Україна, 84100

E-mail: pashchenko zd@i.ua

\section{ГЛАЗОВА Віра}

кандидат педагогічних наук, доцент, доцент кафедри МНМ та МНI, ДВНЗ «ДДПУ»

вул. Г. Батюка, 19, м. Слов’янськ, Донецька обл., Україна, 84100

E-mail: vvglazova@gmail.com

(C) Кайдан Н., Пащенко 3., Глазова В., 2019 